\title{
Gender and Intra-household Allocation of Remittances: Evidence from Estate Sector of Sri Lanka
}

\author{
ABSTRACT \\ R.A.P.I.S. Dharmadasa ${ }^{1}$, J. Weerahewa ${ }^{2}$ and P.A. Samarathunga ${ }^{3}$
}

Using a nationally representative data set, we examine whether the individuals' bargaining power within households affects allocation of remittances in estate households in Sri Lanka. Two separate fractional logit models were estimated within the Engle's Curve framework for male headed and female headed households to examine the intra household bargaining on decision making with respect to resource allocation. The results suggest that while female headed households allocate international remittances on food, male headed households allocate such on housing. The results further reveal that internal remittances contribute more for food, communication, entertainment, non-durables, transport and ad hoc purchases of male headed households. The influence of remitters on allocation for the food expenditure is relatively small but it is high for education, housing, health, consumer goods, durables and expenditure for ad hoc purchases, entertainment and transport. Overall, the study concludes that remitter has a greater say over the allocation of household resources over expenditures other than food and housing whereas household head play a significant role in allocating remittances on food and housing.

Keywords: Fractional logit model, Gender, Household expenditure, Intra household bargaining, Remittances

\footnotetext{
${ }^{1} \mathrm{Ph} . \mathrm{D}$ Candidate, Postgraduate Institute of Agriculture, University of Peradeniya, Sri Lanka

sampath@uwu.com

${ }^{2}$ Department of Agricultural Economics and Business Management

Faculty of Agriculture, University of Peradeniya, Sri Lanka

jeevikaw@pdn.ac.lk

${ }^{3}$ Postgraduate Institute of Agriculture, University of Peradeniya, Sri Lanka parakrama.sam@gmail.com
} 


\section{Introduction}

Remittances received from local and international migration play significant and diverse roles in household economies in developing nations. Their effects on poverty, income distribution, and expenditure pattern of remittance receiving households are well cited. According to Haddad et al. (1997), remittances change the intra-household resource allocation as a result of change in bargaining power of individuals in the family. The remitter can influence over the allocation of resources although he/she is not present in the household. Gender of the remitter and the gender of the receiver of remittances play a major role in this regard. Göbel (2013) states that a higher female intra-household bargaining power leads to higher expenditure on education, health and food. This implies that the allocation of remittances across various expenditure items within a household, that is larely determined by bargaining power of remitter, is context specific and it would have important developmental implications for a society.

Sri Lankan society is characterized as a male dominant society where, in most cases, the principle male becomes the household head (Vithanage, 2015) and he is the main income generator. In the case of the estate sector ${ }^{4}$ of Sri Lanka, women as well as men have the equal access to employment and earnings. However, Ariyarathne et al. (2012) highlight that although women are the main household earners; it is often the male that collects their wages and control their money. On the other hand, the international migrants from estates are women and most of them tend to send remittances home. Therefore, it is the principle male who is engaged in decision making of allocating household resources. However, we can also assume that women also have bargaining power over the allocation of resources as they contribute to the total household income through estate work and remittances. As remittances contribute to the household income, they should have a significance impact on the household resource allocation and the allocation of resources depends on the bargaining power of the individuals in the households. In most cases, the receiver of the remittances is the spouse or the household head. Therefore, the role played by the household head as well as the remitter in allocating the resources is of great importance. Therefore, by considering all these factors, this study attempts to answer the following questions;

\footnotetext{
4 There are three commonly known sectors viz urban, rural and estate. Estate sector consists of all plantations which are 20 acres or more in extent and ten or more resident labourers.
} 
- How does the expenditure pattern of estate households change with the receipt of remittances?

- How do the budget allocations affected by remitter?

- How do budget allocations affected by gender of receiver of the remittances?

\section{Migration, Gender and Expenditure Pattern}

The remittances are considered as part of the development engine in developing communities and nations. The studies conducted in other countries have concluded that remittances are devoted mainly to current consumption instead of investments (Taylor et al., 1996; Chami et al., 2003). This however may not be the case for Sri Lankan estate households as they are provided with most of the infrastructure facilities and in most cases employment opportunities for the descendants of estate families by the estate management. This will enable them to use remittances for investment purposes. The literature related to expenditure patterns of Sri Lankan households highlight the fact that remittances from females are invested in home improvements (renovation and expansion of houses) and acquisition of farm land and nonfarm assets, whereas remittances of men are channelled more toward housing assets and business ventures (De Silva, 2013). Arunatilake et al. (2011) highlight that migrant households spend more on food, non-food, durable goods and housing. Sharma (2013) finds that the cumulative impact of migration and remittance to be significantly positive on key areas such as food consumption, health expenditures, and expenditure on basic non-food goods in Sri Lanka. In general, remittances help families maintain or increase consumption, housing and small business formation (Lasagabaster et al., 2005). However, evidences with regard to impact of remittances on gendered specific expenditure pattern in estate sector of Sri Lanka is lacking and none of the studies cited above has taken the intra-household bargaining process into account.

In allocating the remittances among the different preferences of the household members, basic assumption is that the women have more bargaining power over the use of remittances in female headed households while males have the more bargaining power in male headed households (Guzman et al., 2008). Apart from this assumption, it is assumed that all the migrant remittances are received and controlled by household head. The very reason for this is that, in particular, the head of the household is considered as a proxy for household decision making in maximization of welfare of the entire household. Although we consider the household head as the sole controller of remittances, it 
ignores even male headed households control over remittances could have impact on women's bargaining power and on the ability of the women to influence the resource allocation.

Throughout the literature on gender role and remittances in resource allocation, women have been given the priority and many authors emphasize that household expenditure on children's education, health and nutrition increases when resources are controlled by women (Haddad et al., 1997; Quisumbing and Maluccio, 2000). Guzman et al. (2008), find that remittances affect expenditure shares in female headed households but not in the male headed households.

According to De la Cruz (1995), Mexican migrants in the US direct their remittances towards personal investments in land, housing, agricultural production and cattle. Particularly, female migrants send remittances to pay for cost of education of other household members. In contrast to this Pfeiffer and Taylor (2008) reveal that household with a female remitter invest a smaller share of total expenditure on education than household with a male remitter. They conclude that this result may be due to the intra-household bargaining power. Since women cannot monitor the education of their children, female migration leads to smaller expenses on education although remittances should increase education expenditure.

Generally, literature suggests that women prefer their remittances to be spent on food, clothing, education and health while men direct their remittances towards housing and purchase of consumer durables. This implies that women seem to function as an insurer for their families (Guzman et al., 2008). The main reason highlighted in the literature for the reason of influence of women is that they gain bargaining power over the allocation of household resources due to increase in household income via remittances from their earnings abroad. It is noteworthy to state that many studies cited above have been focused on international migration and the studies to estimate the impact of internal migration on expenditure patterns are lacking.

\section{Data}

Data for this study come from household Income and Expenditure Survey (HIES) conducted by Department of Census and Statistics in 2009/10. The survey was comprehensive, collecting detailed information about wide range of topics like income, expenditure, demographic, education, health, remittances and transfers and assets etc. As this survey was not designed to gather information on 
migrant and remittance information, it had collected data on current remittances and transfers from outside the country and from within the country. HIES provides information on the persons who are members of the households and usually live with them. With respect to migration, the survey collected no information on migrants. The only information we can extract is whether the households receive remittances and where the remittances are coming from. On the other hand, it does not provide any information on either temporary or permanent migration. The survey collected information on remittances for the last 12 calendar months. The data set provides information related to rural, urban and estate sector of Sri Lanka separately.

The data include 54,307 rural household members, 23,346 urban household members and 7,790 estate household members. This study employs only the data that belong to 7,790 estate household members. These members belong to 1736 households. The data include 1,273 non migrant households (73.33\%) and 463 migrant households (26.67\%). Among the migrant households, 331(71.49\%) households are local (internal) migrant households and 93 (20.08\%) households are international migrant households. The rest (39) of the migrant households $(8.43 \%)$ have both internal as well as international migrants. Out of these households, 286 households (61.77\%) receive no remittances, 93 households $(20.08 \%)$ receive internal remittances and 43 households $(9.28 \%)$ receive international remittances. Further, $8.87 \%$ households receive remittances from both sources.

\section{Theoretical Model and Empirical Strategy}

As the study deals with the household expenditure patterns of the remittance receiving and not receiving households and wide range of goods such as food, housing, and education etc. (table 1), the chosen functional form should have the properties of increasing decreasing and constant marginal propensity to spend over wide range of goods and expenditure levels and satisfy the additivity criterion i.e. to be internally consistent, sum of the marginal propensities for all goods should equal unity. In fulfilling those criteria, a form of Working-Lesser model i.e. adjusted Working-Lesser model is used. The equation of interest of household expenditure is derived from the Engel curve framework. It specifies how a consumer's expenditures on some goods or services are allocated. It expresses the share of each consumption item as a linear function of the logarithm of total expenditure, remittances, and socioeconomic characteristics of households.

$q_{i}=g_{i}(y, z)$ 
Where;

$q_{i}=$ Quantity consumed of good $i$

$\mathrm{y}=$ Income, wealth or total expenditure

$\mathrm{z}=$ Vector of other characteristics of a consumer

Engle curve is generally expressed in budget shares and therefore;

$w_{i}=h_{i}[\log (y), z]$

$w_{i}=$ The fraction of $\mathrm{y}$ that is spent on buying good $i$

Accordingly, the expenditure function is set as follows;

$w_{h i}=f\left(p_{h}, y_{h}, z_{h}\right)+u_{h i} \ldots \ldots \ldots \ldots \ldots \ldots \ldots \ldots \ldots$

Where;

Subscript $h$ is Household and $i$ is expenditure category

$w_{h i}=$ Expenditure share on good $i$ in household $h$

$p_{h}=$ Vector of price

$y_{h}=$ Household income

$z_{h}=$ Variables influencing marginal utilities

$u_{h i}=$ Error term

A standard fractional logit model is used in estimating the model (1). Several factors are considered in choosing the fractional logit model. In developing the methodology, it is the recommendation that we must account for non-random selection into groups of remittance receiving and not receiving households. Here, the argument is that if receivers of remittances systematically differ from non-receivers along observable and unobservable dimensions (Acosta, 2006), we cannot simply compare remittance receiving and non-receiving households due to the fact that it generates bias results. In controlling the issue of nonrandomness, an instrumental variable approach is generally used. However, identification of a better instrument is not possible in HIES data as the data set does not provide information to generate an instrumental variable. The next best solution is to use propensity score matching technique as an alternative approach. As there are several comparison groups that demand multinomial approach, it is difficult to implement matching approach as well. Therefore, standard fractional logit model is used where it does not demand instruments (Guzman et al., 2008).

In estimating the fractional logit model, we specify the following functional form; 


$$
\begin{aligned}
& \mathrm{w}_{\mathrm{hij}}=\alpha_{\mathrm{ij}}+\beta_{0 \mathrm{ij}} \mathrm{D}_{-} \text {LOCAL_R }+\beta_{1 \mathrm{ij}} \mathrm{D}_{-} \text {INTER_R }+\beta_{\mathrm{ik}} \log \text { TOTEXP }+ \\
& \gamma_{\mathrm{ij}} \log \mathrm{n}_{\mathrm{jh}}+\theta_{\mathrm{ij}} \mathrm{z}_{\mathrm{hj}}+\mathrm{u}_{\mathrm{hij}}
\end{aligned}
$$

Where;

$\mathrm{w}_{\text {hi }}=$ Budget share of expenditure category $i$ by household $h$ TOTEXP $=$ Total household expenditure

$\mathrm{n}_{\mathrm{h}}=$ Household size

$\mathrm{z}_{\mathrm{h}}=$ Vector of household characteristics that may affect the expenditure behaviour

D_LOCAL_R $=$ Dummy variable ( $1=$ receive local/ internal remittances, $0=$ otherwise)

D_INTER_R $=$ Dummy variable $(1=$ receive international remittances, $0=$ otherwise)

$j$ defines the gender of the household head and $u_{\mathrm{hi}}$ is the error term

The key dependent variables used in the analysis are the budget shares of six broad categories of expenditure items.

Table 1: Expenditure categories - key dependent variables

\begin{tabular}{lll}
\hline $\begin{array}{l}\text { Expenditure } \\
\text { category }\end{array}$ & Description & Examples \\
\hline Food & $\begin{array}{l}\text { Purchased foods } \\
\text { Non purchased foods }\end{array}$ & $\begin{array}{l}\text { Cereals, prepared foods, } \\
\text { vegetables, meat, fats and } \\
\text { oils, sugary, fruits, } \\
\text { condiments, milk and milk } \\
\text { foods, beverages, liquor etc. }\end{array}$ \\
\hline Education & Expenses for education & $\begin{array}{l}\text { Stationeries, school text } \\
\text { books, tuition fees, school } \\
\text { fees etc. }\end{array}$ \\
\hline Housing & Annual use value & $\begin{array}{l}\text { Estimated rental value of } \\
\text { owner occupied housing } \\
\text { units or freely occupied } \\
\text { housing units. }\end{array}$ \\
\hline Health & Health expenses & $\begin{array}{l}\text { Consultant fees, Payments to } \\
\text { medical laboratories for test } \\
\text { analysis, Purchased of } \\
\text { medical and pharmaceutical } \\
\text { products, spectacles etc. }\end{array}$ \\
\hline Consumer goods \\
and durables & $\begin{array}{l}\text { Expenses for consumer } \\
\text { goods and household } \\
\text { durables }\end{array}$ & $\begin{array}{l}\text { Textiles, personal care, } \\
\text { durable goods etc. }\end{array}$ \\
\hline Other & $\begin{array}{l}\text { Expenses for utilities, } \\
\text { transport, } \\
\text { communication, } \\
\text { entertainment, non- } \\
\text { durables }\end{array}$ & $\begin{array}{l}\text { Ad hoc expenditure, } \\
\text { communication, } \\
\text { entertainment, non-durables, } \\
\text { transport }\end{array}$ \\
& & \\
\hline
\end{tabular}


The major challenge facing the research is how to find a variable to capture the intra-household decision making power. HIES data lacks these kind of predetermined exogenous variables typically used to measure the decision making power and the women empowerment (for example wealth upon marriage). However, the best proxy available is the gender of the household head. According to Guzman et al., (2008) the household head is defined as the person who provides most of the needs of the household. Therefore, we can expect him or her to be in a strong bargaining position within the households. Finally, to analyze the impact of gender of the household head on expenditure patterns in remittance receiving households, separate regressions are run for female-headed households and male-headed households.

Apart from the above analysis, gender of the remitter also matters in intra-household decision making. Although the HIES data contain demographic information on household members, the data do not contain information on migrant demographics. However, we can identify the number of migrants in one family and their relationship to the household head. Based on this information, we examine the effect of remitter on the expenditure patterns of the estate households. Some households contain more than one migrant. The migrant could be the spouse, the son/ daughter, the parents or other relative of the household head. When there are more than one migrant, if we assume that all of them remit, there can be several remitters based on the relationship to the household head. For example remitter can be the spouse of the household head. In this case, the gender of the remitter can be identified. But in other cases, when remitter becomes the son/ daughter, the gender could not be identified as the data do not clearly distinguish whether the remitter is the son or daughter. Instead, the data only states the relationship as son/ daughter. On the other hand, if the remitter is the parent of the household head, we cannot identify the gender of the parent. As a result of nature of data available, we categorize the remitters as spouse remitter, Son/ daughter remitter, parent remitter, other relative remitter, spouse/ son/ daughter remitter, and son/ daughter /other remitter. Therefore, they are used as dummy variables. Apart from that, the gender of the household head is included as a dummy variable ( $1=$ female, $0=$ otherwise) to examine the effect of female household head on expenditure pattern. A separate fractional logit model is then estimated to find the impact of remitter on the expenditure pattern.

\section{Model Specification and Descriptive Statistics}

The fractional logit model includes characteristics of household heads, human capital variables and other household characteristics as 
shown in table 2. In identifying those characteristics the standard literature was followed (See Guzman et al., 2008 and Göbel, 2013).

Table 2: Variable definitions

\begin{tabular}{ll}
\hline Variable & Unit of Measurement \\
\hline Age of household head & Years \\
\hline Educational level of household head & Years \\
\hline Sri Lankan Tamil & $\begin{array}{l}\text { Dummy, } 1=\text { Sri Lankan } \\
\text { Tamil, } 0=\text { otherwise }\end{array}$ \\
\hline Indian Tamil & $\begin{array}{l}\text { Dummy, } 1=\text { Indian Tamil, } \\
0=\text { otherwise }\end{array}$ \\
\hline Living in a line room & $\begin{array}{l}\text { Dummy, } 1=\text { living in a line } \\
\text { room, } 0=\text { otherwise }\end{array}$ \\
\hline Living in a single house & $\begin{array}{l}\text { Dummy, } 1=\text { living in a single } \\
\text { house, } 0=\text { otherwise }\end{array}$ \\
\hline Number of males over age 15 & Number \\
\hline Number of females over age 15 & Number \\
\hline Number of male children under age 6 & Number \\
\hline Number of female children under age 6 & Number \\
\hline Number of workers over age 15 & Number \\
\hline $\begin{array}{l}\text { Number of members over age 15 with 12 } \\
\text { years and above education }\end{array}$ & Number \\
\hline $\begin{array}{l}\text { Number of members over age 15 with 6- } \\
11 \text { years of education }\end{array}$ & Number \\
\hline $\begin{array}{l}\text { Number of members over age 15 with 1-5 } \\
\text { years of education }\end{array}$ & Number \\
\hline $\begin{array}{l}\text { Number of members over age 15 with no } \\
\text { schooling }\end{array}$ & Number \\
\hline $\begin{array}{l}\text { Government or semi government employee } \\
\text { of the household head }\end{array}$ & $\begin{array}{l}\text { Dummy, } 1=\text { government or } \\
\text { semi government employee, } \\
0=\text { otherwise }\end{array}$ \\
\hline $\begin{array}{l}\text { Private sector employee of the household } \\
\text { head }\end{array}$ & $\begin{array}{l}\text { Dummy, } 1=\text { private sector } \\
\text { employee, } 0=\text { otherwise }\end{array}$ \\
\hline region_1 Western Province & Dummy, $1=$ region_1 \\
\hline region_2 Central Province & Dummy, $1=$ region_2 \\
\hline region_3 Southern Province & Dummy, 1= region_3 \\
\hline region_4 North Western Province & Dummy, $1=$ region_4 \\
\hline region_5 Uva Province & Dummy, 1= region_5 \\
\hline
\end{tabular}

We could see several interesting contrasts between female headed and male headed households (see Table 3). Accordingly, number of females in the female headed households is significantly higher than those in male headed households while number of males in the male headed households is significantly higher than those in female headed households. Female headed households have more schooling age children and children under age 6 . Male headed households have more 
workers over age 15 . This implies that male headed households have better endowment of human resources. Male household heads are more educated. Although the difference in educated years is significant, all of them have primary education. The Table 3 further indicates that the total annual expenditure in male headed households is also greater than that of female headed households. 
Table 3: Descriptive statistics of selected variables

$*, * *, * * *$ Significant at 10, 5 and 1 percent probability level

\begin{tabular}{|c|c|c|c|c|c|c|c|c|c|c|c|}
\hline \multirow{2}{*}{ Variable } & \multicolumn{5}{|c|}{ Female Headed Households } & \multicolumn{5}{|c|}{ Male Headed Households } & \multirow[b]{2}{*}{ T- test } \\
\hline & Obs & Mean & Std. Dev. & Min & Max & Obs & Mean & Std. Dev. & Min & Max & \\
\hline Age of the household head & 166 & 49.13 & 13.15 & 18 & 81 & 297 & 50.72 & 12.72 & 18 & 92 & -1.278 \\
\hline $\begin{array}{l}\text { Education level of the household } \\
\text { head }\end{array}$ & 166 & 3.99 & 3.59 & 0 & 17 & 297 & 5.21 & 3.16 & 0 & 16 & $-3.81 * * *$ \\
\hline Household Size & 166 & 5.47 & 1.90 & 2 & 13 & 297 & 5.54 & 1.96 & 2 & 17 & -0.38 \\
\hline Number of males over age 15 & 166 & 2.04 & 1.16 & 0 & 6 & 297 & 2.64 & 1.05 & 1 & 7 & $-5.63 * * *$ \\
\hline Number of females over age 15 & 166 & 1.99 & .97 & 1 & 6 & 297 & 1.75 & 1.00 & 0 & 7 & $2.49 * *$ \\
\hline $\begin{array}{l}\text { Number of male children under age } \\
6\end{array}$ & 166 & .24 & .45 & 0 & 2 & 297 & .17 & .44 & 0 & 2 & $1.45^{*}$ \\
\hline $\begin{array}{l}\text { Number of female children under } \\
\text { age } 6\end{array}$ & 166 & .18 & .47 & 0 & 3 & 297 & .18 & .43 & 0 & 2 & 0.113 \\
\hline $\begin{array}{l}\text { Number of male children age } \\
\text { between } 6-15\end{array}$ & 166 & .56 & .81 & 0 & 3 & 297 & .34 & .59 & 0 & 4 & $3.35 * * *$ \\
\hline $\begin{array}{l}\text { Number of female children age } \\
\text { between } 6-15\end{array}$ & 166 & .45 & .69 & 0 & 3 & 297 & .46 & .78 & 0 & 5 & -0.08 \\
\hline Number of workers over age 15 & 166 & 1.18 & 1.03 & 0 & 5 & 297 & 1.70 & .95 & 0 & 6 & $-5.47 * * *$ \\
\hline $\begin{array}{l}\text { Number of members over age } 15 \\
\text { with } 12 \text { years and above education }\end{array}$ & 166 & .07 & .28 & 0 & 2 & 297 & .11 & .39 & 0 & 3 & -1.12 \\
\hline $\begin{array}{l}\text { Number of members over age } 15 \\
\text { with 6- } 11 \text { years of education }\end{array}$ & 166 & 1.15 & 1.05 & 0 & 4 & 297 & 1.18 & 1.11 & 0 & 5 & -0.29 \\
\hline $\begin{array}{l}\text { Number of members over age } 15 \\
\text { with } 1-5 \text { years of education }\end{array}$ & 166 & .76 & .78 & 0 & 4 & 297 & 1.24 & .94 & 0 & 5 & $-5.56^{* * *}$ \\
\hline $\begin{array}{l}\text { Number of members over age } 15 \\
\text { with no schooling }\end{array}$ & 166 & .43 & .67 & 0 & 4 & 297 & .38 & .66 & 0 & 4 & 0.68 \\
\hline Per capita expenditure per year & 166 & 44748.72 & 21134.03 & 12056.58 & 136454.9 & 297 & 55502.56 & 48916.61 & 11942.4 & 500703.7 & $-2.69 * *$ \\
\hline
\end{tabular}




\section{Results and Discussion}

\section{Impact of Migration and Remittances on Gendered Specific Expenditure Pattern}

The main objective of this study is to find the impact on remittances on expenditure pattern of estate households in Sri Lanka by taking the intra-household bargaining process into account. Accordingly, the results reveal that (table 4) receipt of internal remittances exerts statistically significant effect on food share in male headed households. The positive sign of the co-efficient indicates that receipt of internal remittances allows a greater family spending on food consumption of male headed households. On the other hand, the estimated coefficient capturing the effect of receipt of remittance from international migration is statistically significant with a negative sign in female headed households. That is, the receipt of international remittances reduces the expenditure share on food in the female headed households. On the whole, both internal as well as international remittances have a negative effect on the food expenditure share on female headed households while international remittances have a positive effect on the food expenditure share in male headed households. The reason behind this finding is that most of the migrant from estate sector are internal migrants and they do ad hoc jobs outside the estate (World Bank, 2007). Their earnings are not substantial. Therefore, the amount of remittances that the internal migrants send is less and those remittances are spent on consumption of food while international remittances are used for purposes other than food consumption.

Attention now turns to estimates concerning expenditure share on education. Expenditure devoted to education significantly increases with the increase in total household expenditure in male headed households although it is not significant in female headed households. Household size is a significant determinant of education share in both types of households implying that they invest more on education with the increase in the household size. 
Table 4: Fractional logit outputs by gender and expenditure category

\begin{tabular}{|c|c|c|c|c|c|c|}
\hline Variable & & & Edu & & Ho & \\
\hline & $\begin{array}{r}\text { Male Headed } \\
\text { Households } \\
\end{array}$ & $\begin{array}{r}\text { Female Headed } \\
\text { Households }\end{array}$ & $\begin{array}{r}\text { Male Headed } \\
\text { Households }\end{array}$ & $\begin{array}{r}\text { Female Headed } \\
\text { Households } \\
\end{array}$ & $\begin{array}{r}\text { Male Headed } \\
\text { Households }\end{array}$ & $\begin{array}{r}\text { Female Headed } \\
\text { Households }\end{array}$ \\
\hline Age of household head & .0062 & $-.0366^{* *}$ & $-.1388 * *$ & .1048 & .0158 & $.0339 *$ \\
\hline Squared Age of household head & -.00005 & $.00043 * * *$ & $.0011 * *$ & -.0009 & -.0001 & -.0002 \\
\hline $\begin{array}{l}\text { Educational level of household } \\
\text { head }\end{array}$ & -.0175 & $-.026 *$ & $-.1342 * *$ & .0046 & $.0532 * *$ & .0230 \\
\hline Log of household size & $.8740 * * *$ & $.7246 * * *$ & $2.8706 * * *$ & $3.1289 * * *$ & $-1.1668 * * *$ & -.1805 \\
\hline Sri Lankan Tamil & .07176 & .0577 & -.3501 & $-1.4752 * * *$ & $-.4453 * *$ & -.0939 \\
\hline Indian Tamil & .0453 & -.0183 & .7238 & -.4345 & $-.6410 * * *$ & $-.2653 * *$ \\
\hline Living in a line room & -.0706 & -.0089 & .3982 & .2758 & .0515 & .3246 \\
\hline Living in a single house & -.0700 & .0301 & .6023 & -.0149 & .0723 & .0998 \\
\hline Number of males over age 15 & $-.1270 * * *$ & $-.1842 * * *$ & $-.6537 * * *$ & $-.7223 * * *$ & $.2315 * * *$ & $.1802 * * *$ \\
\hline Number of females over age 15 & -.1044 & $-.2847 * * *$ & $-.5058 * *$ & $-1.5567 * * *$ & $.2079 * *$ & -.0075 \\
\hline $\begin{array}{l}\text { Number of male children under } \\
\text { age } 6\end{array}$ & -.0437 & .1401 & -.4928 & $-.8276^{* *}$ & .2048 & -.0999 \\
\hline $\begin{array}{l}\text { Number of female children } \\
\text { under age } 6\end{array}$ & -.0191 & -.01099 & $-.6565 * *$ & .0573 & .15164 & .0501 \\
\hline Number of workers over age 15 & -.0221 & .01834 & $-.2608 *$ & -.1826 & -.0750 & $-.2186 * * *$ \\
\hline $\begin{array}{l}\text { Number of members over age } 15 \\
\text { with } 12 \text { years and above } \\
\text { education }\end{array}$ & -.0472 & .0150 & .4866 & $1.1358 *$ & -.1326 & -.1583 \\
\hline $\begin{array}{l}\text { Number of members over age } 15 \\
\text { with } 6-11 \text { years of education }\end{array}$ & $.1506^{* *}$ & $.2286 * * *$ & .0923 & $.6369 * *$ & -.0981 & .0014 \\
\hline $\begin{array}{l}\text { Number of members over age } 15 \\
\text { with } 1-5 \text { years of education }\end{array}$ & .0948 & $.2703 * * *$ & -.0991 & .4878 & .0797 & -.0468 \\
\hline
\end{tabular}




\begin{tabular}{|c|c|c|c|c|c|c|}
\hline Log of expenditure & $-.9312 * * *$ & $-.5469 * * *$ & $.6321 * * *$ & .1737 & -.1537 & $-.5235 * * *$ \\
\hline $\begin{array}{l}\text { Receipt of International } \\
\text { Remittances }\end{array}$ & .0688 & $-.2499 *$ & -.1156 & -.0362 & $.3242 * *$ & .2501 \\
\hline Receipt of Internal Remittances & $.1827 * *$ & -.0486 & .07669 & -.3790 & .1599 & -.0286 \\
\hline $\begin{array}{l}\text { Government or semi government } \\
\text { employee of the household head }\end{array}$ & .0511 & .0137 & -.6296 & -.3223 & .0693 & .0934 \\
\hline $\begin{array}{l}\text { Private sector employee of the } \\
\text { household head }\end{array}$ & $.1684 *$ & -.0537 & .2230 & $.8102 * *$ & -.0588 & -.1554 \\
\hline region_1 Western Province & .0335 & -.1203 & -.1201 & .6985 & -.0680 & -.2951 \\
\hline region_2 Central Province & $.2299 *$ & .1149 & -.0809 & -.2406 & -.1691 & -.0981 \\
\hline region_3 Southern Province & $-.2317 *$ & $-.5116 * * *$ & .1640 & -1.3121 & .0072 & .2643 \\
\hline $\begin{array}{l}\text { region_4 North Western } \\
\text { Province }\end{array}$ & -.0013 & .2229 & -1.0571 & -.07574 & $-.4991 * *$ & .37839 \\
\hline region_5 Uva Province & .0992 & -.1874 & -.0698 & $1.4527 * * *$ & -.0705 & -.2231 \\
\hline Constant & $10.4151 * * *$ & $7.1121 * * *$ & $-9.9836 * * *$ & $-10.0856 * *$ & -.2762 & 2.6551 \\
\hline $\mathrm{N}$ & 297 & 166 & 297 & 166 & 297 & 166 \\
\hline Significance & 0.0000 & 0.0000 & 0.0000 & 0.0000 & 0.0000 & 0.0000 \\
\hline Pseudo $\mathrm{R}^{2}$ & 0.0367 & 0.0273 & 0.0747 & 0.1311 & 0.0167 & 0.0262 \\
\hline
\end{tabular}

$*, * *, * * *$ Significant at 10,5 and 1 percent probability level 
With respect to education share, the results also suggest that expenditure share allocated for education decreases with the increase in number of male and female household members aged over 15 , number of siblings aged below 6 and number of employed members in both household types except for female siblings aged below 6 years. The remittances sent to origin community represent an important resource that can be devoted to the development of physical and human capital. The developmental impact of remittances depends on whether the remittances are spent on consumption or investment. The decision to invest or consume depends on the bargaining power of the household members. Education level of the migrant as well as the education level of the other household members affects the migration decision positively. The results suggest that having more members with 6-11 years education level and advanced level and above education level are important determinants of expenditure share on education in the female headed households. The variables are positive indicators of male headed households as well and it implies that they also invest more on education with the increase in number of educated members. Most importantly, the expectation is that these households should invest more on education with the receipt of remittances. However, the results suggest that receipt of remittances is not a significant determinant in expenditure share on education. This could be due to the fact that income from different sources may not have pooled together and some family members may have distinct preferences and distinct bargaining powers.

Fractional logit results of housing share indicate that household size is an important determinant of housing share of male headed households. Negative sign of the coefficient suggests that increase in household size leads to decrease in expenditure for housing. Total expenditure is also a significant indicator of expenditure on housing share and the results show that the increase in total expenditure leads to decrease in housing expenditure share of the female headed households. Apart from those findings, female headed households as well as male headed invest more on housing when they have more members over age 15 while number of employees in the female headed households contributes negatively for the expenditure on housing. Many people who work in estates live in line rooms most of them work in estates. As the line space is very limited, they do not need to spend on housing. It is also seen from the results that human capital variables do not have a significant effect on housing expenditure share. International remittance receiving male headed households invest on housing while female headed households also tend to invest on it. It is also noted that contribution from internal remittances is positive in investing on housing of male headed households while it is negative in female headed 
households. HIES data reveal that about $60.69 \%$ households still lives in lines while about $26.77 \%$ lives in single houses. Most of these household members belong either to Sri Lankan Tamils or Indian Tamils. The results of the fractional logit model on housing share further suggest that being an Indian Household reduces the expenditure on housing in male headed households.

Health expenses significantly increase when the total expenditure increases in both types of households. The households are more concerned on their health when their income increases. Moreover, with the increase in number of employed members in the households, the male headed as well as female headed households allocate less of their income to health. The estate areas in most cases are isolated from the rest of the Sri Lankan society. The estate management is responsible for providing most of the needs of the estate employees. Generally, estates have a hospital where the treatment is given free of charge like in other areas. When a person is sick, nowadays most of the people tend seek medical treatment from private medical practitioners. In most cases, estate employees do not have an access to private medical practitioners. Therefore, their private money may not be spent on medical treatment from outside. That could be a reason why they spend less on health. However, they have inclined to spend on health when they have more children under age 6 except for female children in male headed households. With the receipt of the remittances either from abroad or Sri Lanka, male headed households spend less on health. However, female headed households tend to spend more on their health with the increase in receipt of internal remittances. Having more number of members with better education leads to reduce the expenditure share on health in male headed households although it shows no statistical significance. Apart from these findings, education level of the household head is a significant determinant in expenditure allocated to health. It is obvious that people are more concerned of their health when they are more educated.

The expenditure share devoted to consumer goods and durables significantly increases with the increase in adult males, adult females and the little female children. Receipt of remittances also does not have a significant effect on this budget share. In deciding the allocation of money to this expenditure category, the education level of the household plays a significant role and it changes the bargaining power of the household.

The last expenditure category (other) comprises of expenditure on communication, entertainment, non-durables, transport and ad hoc 
items. Remittances do not have a significant impact on this expenditure category of either household. With the increase in total expenditure, the budget share allocated to this category is increased while it is decreased with the increase in the household size in both types of households. However household size affects the expenditure share negatively. Number of adult males and females, number of employees, being an Indian Tamil or a Sri Lankan Tamil household tends to increase the expenditure share for this category. With the increase in the number of educated persons in the household the expenditure devoted to this category decreases. 
Table 4: Fractional logit outputs by gender and expenditure category (continued)

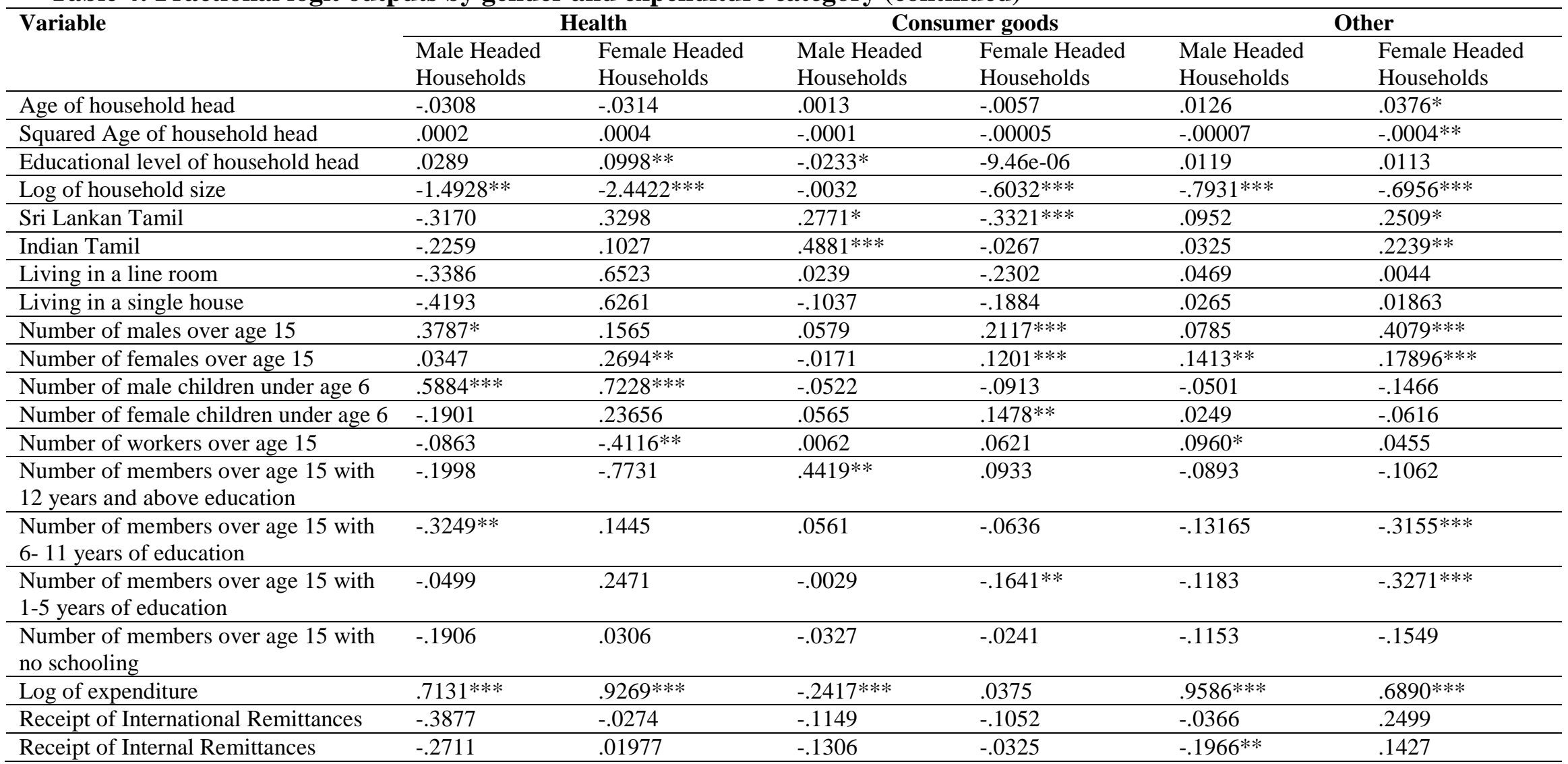




\begin{tabular}{|c|c|c|c|c|c|c|}
\hline $\begin{array}{l}\text { Government or semi government } \\
\text { employee of the household head }\end{array}$ & -.0628 & -.0965 & -.0399 & -.1045 & -.0532 & .0586 \\
\hline $\begin{array}{l}\text { Private sector employee of the } \\
\text { household head }\end{array}$ & $-.9663 * * *$ & $.7192 * *$ & -.0909 & -.0306 & -.0966 & -.03565 \\
\hline region_1 Western Province & .3050 & -.0123 & $.2032 *$ & -.1669 & -.0532 & .1035 \\
\hline region_2 Central Province & $-.9529 * *$ & .1193 & .1919 & .0307 & -.1251 & -.1728 \\
\hline region_3 Southern Province & .51673 & -.2320 & .1738 & $-.4615 * * *$ & .1586 & $.8006^{* * *}$ \\
\hline region_4 North Western Province & $-2.1062 * * *$ & -.9035 & .4853 & $-1.2430 * * *$ & .05208 & -.0079 \\
\hline region_6 Uva’ Province & -.1883 & -.3224 & .0596 & -.0668 & -.1185 & .08494 \\
\hline Constant & $-8.2403 * *$ & $-13.4016 * * *$ & .1903 & -1.7289 & $-12.4659 * * *$ & $-10.0096 * * *$ \\
\hline $\mathrm{N}$ & 297 & 166 & 297 & 166 & 297 & 166 \\
\hline Significance & 0.0000 & 0.0000 & 0.0000 & 0.0000 & 0.0000 & 0.0000 \\
\hline Pseudo $\mathrm{R}^{2}$ & 0.1184 & 0.0552 & 0.0069 & 0.0095 & 0.0358 & 0.0368 \\
\hline
\end{tabular}

$*, * *, * * *$ Significant at 10,5 and 1 percent probability level 
The Table 5 shows the elasticity values in relation to total expenditure and expenditure category. The results clearly suggest that 1 percent increase in expenditure of the household leads to 2.655 and 1.54 percent reduction in food expenditure share in male headed and female headed households respectively. If the reduction in food share is compared between two types of households, it is evident that reduction in food expenditure share is higher in male headed households than that of female headed households. With the increase in the internal remittances, male headed households tend to spend more on food consumption while with the increase in international remittances, female headed households tend to reduce the food consumption. It is also observed that male headed households devote more on education than female headed households. When expenditure increases by 1 percent, males spend approximately 0.063 percent higher on education expenditure. It is evident from the descriptive statistics that male household heads are more educated than the female household heads. Therefore, it could be assumed that male household heads want their children also to be more educated. Remittances do not have a significant effect on education share. Male headed households prefer more to spend their international remittance income on housing. However, both types of households do not prefer to allocate more money on housing when their total income levels increase. This may be due to the fact that most of their dwellings are still lines and they do not owe a land to invest. Even if some live in single houses, their land size is very small. Therefore, they may not prefer to spend more on housing with the increase in their expenditure. It should also be highlighted that women are more concerned on their health and the health of others. They prefer to spend more on health than their counterparts. Females spend $0.03 \%$ more on health than males. Remittances do not exert significant effect on the health share of the household expenditure. There is a significant contrast in elasticity values with regard to consumer goods and durables i.e. male headed households do not tend to increase their expenditure share on consumer goods and durables while female headed households prefer to invest on durables and spend more on consumer goods with the increase in the total income. However, remittances do not have a significant effect on this expenditure category. The signs of the coefficient of remittances suggest that they invest less on consumer goods and durables with gaining remittances. Finally, it is interesting to see that estate households like to spend more on entertainment, communication, transport and ad hoc items. This may be due to the fact that they spend their money on conspicuous consumption. Local remittances have a negative impact on this expenditure share of male headed households and opposite can be seen in female headed households. 
Table 5: Estimated elasticities by gender and expenditure category

\begin{tabular}{lcc}
\hline Expenditure Category & $\begin{array}{c}\text { Male Headed } \\
\text { Household }\end{array}$ & $\begin{array}{c}\text { Female Headed } \\
\text { Household }\end{array}$ \\
\hline Food & -2.6551 & -1.540474 \\
\hline Education & 0.1239 & 0.0508 \\
\hline Housing & -0.0886 & -0.2844 \\
\hline Health & 0.1482 & 0.1784 \\
\hline $\begin{array}{l}\text { Consumer goods and } \\
\text { durables }\end{array}$ & -0.1922 & 0.0333 \\
\hline Other & 2.1471 & 1.4156 \\
\hline
\end{tabular}

Having analyzed the expenditure patterns of female headed and male headed households separately, we pooled the data set and ran the fractional logit regression for all migrant households. Here, we included gender (dummy variable indicating $1=$ female and $0=$ otherwise) of the household head as a separate predictor of the expenditure share. We also included two interaction terms (gender * receipt of abroad remittances and gender*receipt of local remittances) to capture the importance of gender of household head in allocating remittances. The results reveal (Table 6) that the interaction term for gender and remittances is significant for food share and the expenditure share related to ad hoc expenditures, transport, entertainment, communication etc. This implies that gender difference is an important factor in allocating remittances for those expenditure categories. It is interesting to note that gender of the household head (being a female) positively affect the education expenditure. 
Table 6: Fractional logit outputs of pooled sample by expenditure category

\begin{tabular}{|c|c|c|c|c|c|c|}
\hline Variable & Food & Education & Housing & Health & $\begin{array}{l}\text { Consumer } \\
\text { Goods }\end{array}$ & Other \\
\hline Age of household head & -.0043 & -.0674 & .0182 & -.0472 & .0007 & .0188 \\
\hline Squared Age of household head & .00007 & .0005 & -.0001 & .0004 & -.0001 & -.0002 \\
\hline Educational level of household head & $-.0161^{*}$ & -.0322 & $.0266^{*}$ & .0404 & -.0055 & .0083 \\
\hline Log of household size & $.8108 * * *$ & $2.5105^{* * *}$ & $-.8178 * * *$ & $-1.6517 * * *$ & $-.2549 *$ & $-.7348 * * *$ \\
\hline Sri Lankan Tamil & $.1703^{*}$ & $-1.1352 * * *$ & $-.4312 * * *$ & -.2098 & .0084 & .1030 \\
\hline Indian Tamil & .0973 & -.0861 & $-.5827 * * *$ & -.1987 & $.2314 * *$ & .0662 \\
\hline Living in a line room & -.0338 & .2149 & .1499 & -.1135 & -.0625 & .0280 \\
\hline Living in a single house & -.0229 & .1323 & .0909 & -.1838 & -.1273 & .0226 \\
\hline Number of males over age 15 & $-.1467 * * *$ & $-.5750 * * *$ & $.2309 * * *$ & .1396 & .0440 & $.1408 * * *$ \\
\hline Number of females over age 15 & $-.1687 * * *$ & $-.7622 * * *$ & $.1415^{*}$ & $.3419 * *$ & $.12463 * *$ & $.1785 * * *$ \\
\hline Number of male children under age 6 & -.0197 & $-.4781 * *$ & .1213 & $.6015 * * *$ & -.0797 & -.0417 \\
\hline $\begin{array}{l}\text { Number of female children under } \\
\text { age } 6\end{array}$ & -.0105 & -.2417 & .1118 & -.1183 & $.1178 * *$ & -.0141 \\
\hline Number of workers over age 15 & .0102 & $-.2804 * *$ & $-.1439 * *$ & $-.1696^{*}$ & .0332 & .0616 \\
\hline $\begin{array}{l}\text { Number of members over age } 15 \\
\text { with } 12 \text { years and above education }\end{array}$ & -.0485 & $.6097 * *$ & -.1063 & -.3382 & $.2906 * *$ & -.0488 \\
\hline $\begin{array}{l}\text { Number of members over age } 15 \\
\text { with 6- } 11 \text { years of education }\end{array}$ & $.1811 * * *$ & $.3480 * *$ & -.0772 & $-.2241 *$ & .0114 & $-.1982 * * *$ \\
\hline $\begin{array}{l}\text { Number of members over age } 15 \\
\text { with } 1-5 \text { years of education }\end{array}$ & $.1594 * * *$ & .2654 & .0171 & -.0231 & -.0511 & $-.1932 * * *$ \\
\hline $\begin{array}{l}\text { Number of members over age } 15 \\
\text { with no schooling }\end{array}$ & $.1448 * *$ & .0578 & -.05763 & -.2295 & -.0293 & $-.1658 * *$ \\
\hline Log of expenditure & $-.7709 * * *$ & $.4209 * * *$ & $-.2364 * *$ & $.8507 * * *$ & $-.1932 * *$ & $.8609 * * *$ \\
\hline
\end{tabular}




\begin{tabular}{|c|c|c|c|c|c|c|}
\hline Receipt of International Remittances & .0495 & .3566 & $.3110 * *$ & -.3547 & -.0805 & -.0802 \\
\hline Receipt of Internal Remittances & $.2006 * *$ & .0149 & .1045 & $-.4106 *$ & -.1240 & $-.1869 *$ \\
\hline Female Household Head & .0034 & $.6621 * *$ & .0477 & -.1219 & .0595 & -.1249 \\
\hline $\begin{array}{l}\text { Gender *receipt of abroad } \\
\text { remittances }\end{array}$ & -.2664 & -.9203 & -.1511 & -.0459 & .0475 & $.4266^{* *}$ \\
\hline gender*receipt of local remittances & $-.2641 * *$ & -.5714 & -.1956 & .4678 & .0984 & $.3864 * * *$ \\
\hline $\begin{array}{l}\text { Government or semi government } \\
\text { employee of the household head }\end{array}$ & .0371 & -.2136 & .0738 & -.0293 & -.0777 & -.01793 \\
\hline $\begin{array}{l}\text { Private sector employee of the } \\
\text { household head }\end{array}$ & .1126 & $.6307 * *$ & -.1011 & $-.5082 * * *$ & -.0758 & -.0811 \\
\hline region_1 Western Province & -.0233 & .0761 & -.1213 & .2563 & .0648 & -.0058 \\
\hline region_2 Central Province & $.17616^{*}$ & -.2288 & -.1514 & $-.6794 * *$ & .1335 & -.1324 \\
\hline region_3 Southern Province & $-.3509 * * *$ & -.0520 & .0013 & .3559 & -.0285 & $.4146^{* * *}$ \\
\hline region_4 North Western Province & .0441 & -.2338 & $-.4202 * *$ & $-2.0174 * * *$ & .2891 & .01645 \\
\hline region_6 Uva`Province & -.00234 & .6070 & -.1661 & -.31429 & .0006 & -.0356 \\
\hline Constant & $8.6786^{* * *}$ & $-9.1904 * *$ & .5357 & $-10.2232 * * *$ & .0481 & $-11.3304 * * *$ \\
\hline $\mathrm{N}$ & 463 & 463 & 463 & 463 & 463 & 463 \\
\hline Significance & 0.0000 & 0.0000 & 0.0000 & 0.0000 & 0.0000 & 0.0000 \\
\hline Pseudo $\mathrm{R}^{2}$ & 0.0306 & 0.0753 & 0.0161 & 0.0826 & 0.0064 & 0.0331 \\
\hline
\end{tabular}

$*, * *, * * *$ Significant at 10,5 and 1 percent probability level 


\section{Impact of Remitter on the Expenditure Pattern}

The results (table 7) suggest that with the increase in the income households tend to decrease the expenditure on food, housing and consumer goods and durables whereas they tend to spend more on education, health, entertainment, transport, communication, ad hoc items etc. If the migrant/ migrants is/are spouse, son/ daughter, son/ daughter and other relative, spouse son/daughter or other relative of the household head, the contribution by them for the food expenditure share decreases while their presence as a migrant to the household increases the education share, housing share, health share, consumer goods and durables and expenditure for ad hoc purchases, entertainment, transport etc. (other share). The main weakness in the results is that we cannot observe the effect of son or daughter separately based on their gender as such type of data are not available in HIES data set. One important implication is that female household heads in the remittance receiving households spend less on food and more on health and the goods related to "other" expenditure category. Results also reveal that with the increase of the percentage of remittances, estate households tend to spend more money on utilities, transport, communication, entertainment, non- durables while they spend less on foods. 
Table 7: Fractional logit outputs including remitters by expenditure category

\begin{tabular}{|c|c|c|c|c|c|c|}
\hline Variable & Food & Education & Housing & Health & $\begin{array}{l}\text { Consumer } \\
\text { Durables }\end{array}$ & Other \\
\hline Age of household head & $.0352 *$ & -.0753 & -.0131 & $-.1067 * * *$ & -.0158 & -.01432 \\
\hline Squared Age of household head & -.0003 & .0006 & .00006 & $.0009 * * *$ & .00009 & .0002 \\
\hline Educational level of household head & .0055 & $-.1279 * *$ & -.0004 & $.1428 * * *$ & -.0242 & .0111 \\
\hline Log of household size & $.6171 * * *$ & $2.1910^{* *}$ & $-.9659 * * *$ & $-1.0381^{*}$ & $-.6348 * * *$ & -.3905 \\
\hline Sri Lankan Tamil & .0192 & -.9953 & -.1089 & .2557 & .0294 & .0214 \\
\hline Indian Tamil & -.1712 & -.9375 & .1935 & .4512 & .0612 & .1585 \\
\hline Living in a line room & .0364 & -.2769 & $-.3418 *$ & .2937 & -.0490 & .12757 \\
\hline Living in a single house & -.0549 & -.0522 & $-.5719 * * *$ & .4143 & .2270 & .1777 \\
\hline Number of males over age 15 & -.1003 & $-.7350 * *$ & .0792 & -.0516 & $.1106^{*}$ & .1481 \\
\hline Number of females over age 15 & -.1582 & $-.9165 * *$ & .1516 & -.3823 & $.1643 *$ & .2187 \\
\hline Number of male children under age 6 & -.1047 & $-1.0074 * * *$ & .2275 & .1934 & -.0604 & .15356 \\
\hline $\begin{array}{l}\text { Number of female children under age } \\
6\end{array}$ & .0242 & $-.6142 * * *$ & .1249 & .0909 & .1119 & -.0579 \\
\hline Number of workers over age 15 & -.0390 & -.1046 & .0168 & -.1390 & .0389 & .0506 \\
\hline $\begin{array}{l}\text { Number of members over age } 15 \text { with } \\
12 \text { years and above education }\end{array}$ & -.0327 & .5421 & -.1182 & $-.6497 *$ & .0755 & .0213 \\
\hline $\begin{array}{l}\text { Number of members over age } 15 \text { with } \\
6-11 \text { years of education }\end{array}$ & .1448 & $.7566^{*}$ & .0821 & .2743 & -.0249 & $-.2905 * *$ \\
\hline $\begin{array}{l}\text { Number of members over age } 15 \text { with } \\
1-5 \text { years of education }\end{array}$ & .1185 & .3983 & $.2656^{* *}$ & $.5666 * *$ & -.0908 & $-.2513 *$ \\
\hline $\begin{array}{l}\text { Number of members over age } 15 \text { with } \\
\text { no schooling }\end{array}$ & .1946 & .2657 & .0113 & .0966 & -.0875 & $-.2498 *$ \\
\hline Log of expenditure & $-.6242 * * *$ & .1884 & $-.4567 * * *$ & .2360 & -.0108 & $.9126 * * *$ \\
\hline
\end{tabular}




\begin{tabular}{|c|c|c|c|c|c|c|}
\hline Female household head & $-.2284 * *$ & -.1353 & -.1271 & $.7069 * *$ & .0226 & $.3652 * *$ \\
\hline Internal Migrant Household & $.4943 * *$ & .1352 & .1544 & .1407 & -.2418 & $-.6808 * * *$ \\
\hline International Migrant Household & .2032 & .4271 & .3251 & .2034 & $-.3331 * *$ & -.2979 \\
\hline Percentage of Remittances Received & $-.0019 * * *$ & .0020 & -.0004 & .0016 & -.0003 & $.0025 * * *$ \\
\hline $\begin{array}{l}\text { Remitter is a son/ Daughter or Other } \\
\text { Relative }\end{array}$ & $-.6107 * *$ & $1.5673^{*}$ & $1.1559 *$ & $3.3140 * * *$ & .2409 & .0442 \\
\hline $\begin{array}{l}\text { Remitter is the spouse of the } \\
\text { household head }\end{array}$ & $-.7277 * * *$ & $1.3479 *$ & 1.0047 & $2.8348 * * *$ & .3144 & .2942 \\
\hline Remitter is a son or daughter & $-.9183 * * *$ & 1.0852 & $1.0474^{*}$ & $3.4047 * * *$ & -.0058 & $.6759 * *$ \\
\hline Remitter is an other relative & $-.6927 * *$ & $1.2738^{*}$ & .87990 & $2.9084 * * *$ & .2463 & .3272 \\
\hline Remitter is a son; daughter or spouse & $-1.0872 * * *$ & $1.7625 * *$ & $1.1304 *$ & $3.0490 * * *$ & .3634 & $.6155^{*}$ \\
\hline $\begin{array}{l}\text { Government or semi government } \\
\text { employee of the household head }\end{array}$ & .12811 & $-1.0813 *$ & -.0807 & $-.6073 * *$ & -.0389 & .0356 \\
\hline $\begin{array}{l}\text { Private sector employee of the } \\
\text { household head }\end{array}$ & .0533 & .1090 & -.1733 & -.1767 & -.0029 & .03028 \\
\hline region_1 Western Province & -.0749 & .01370 & $-.3669 *$ & $.5317 *$ & $-.2689 *$ & .1454 \\
\hline region_2 Central Province & .0547 & .2132 & .0604 & $-.9204 * * *$ & -.0418 & .0005 \\
\hline region_3 Southern Province & $-.5121 * *$ & -1.0794 & -.0366 & .0340 & .1634 & $.6241 *$ \\
\hline region_4 North Western Province & -.1862 & .9565 & .0736 & $-1.6030 * *$ & -.2459 & -.0272 \\
\hline region_6 Uva`Province & .1240 & $1.003 * *$ & -.2731 & $-1.1499 * * *$ & $-.3449 * * *$ & $2.24 \mathrm{e}-07$ \\
\hline Constant & $7.027 * * *$ & -5.5399 & 3.0752 & $-6.9869 * *$ & -1.2408 & $-12.1701 * * *$ \\
\hline $\mathrm{N}$ & 175 & 175 & 175 & 175 & 175 & 175 \\
\hline Significance & 0.0000 & 0.0000 & 0.0000 & 0.0000 & 0.0000 & 0.0000 \\
\hline Pseudo $\mathrm{R}^{2}$ & 0.0227 & 0.0900 & 0.0209 & 0.0826 & 0.0103 & 0.0352 \\
\hline
\end{tabular}

*,**,*** Significant at 10,5 and 1 percent probability level 


\section{Conclusions}

Literature on estimating the impact of migration and remittances on gendered specific expenditure pattern supports the view that women tend to spend more on education, health and nutrition when they are of control over the allocation of household resources. One argument is that women working abroad may gain bargaining power over the household resource allocation as they contribute to increase the income of the households through remittances. However, there is a counter argument that remitters may have a little influence over the allocation as the remitter herself/himself is not present in family so that his influence on resource allocation could be at minimum. This is called as principle agent problem and it should be controlled for in any analysis related to estimating impact of remittances on gendered specific expenditure pattern. Therefore, the gender of the remitter could be included as a predictor in the expenditure analysis. Once this principle agent problem is controlled for, the findings from the literature suggest that women migrant invest their money on education of their children (human capital improvements), health etc. while male migrants prefer their remittances to invest on land housing and other assets. Therefore, it is an essential fact to understand what results of the HIES data analysis on expenditure pattern reveal in relation to the intra-household resource allocation in estate sector of Sri Lanka. The results give rise to several important implications which are consistent with the existing literature.

The econometric results suggest a significant association between the receipt of remittances and the spending patterns across different commodity groups of male headed and female headed households. The results suggest that female headed households reduce the food expenditure with the receipt of international remittances and male headed households spend more on food with the receipt of internal remittances. As shown by the results, male headed households invest on housing with the receipt of international remittances and spend less budget share on ad hoc items, non-durables, communication and transport etc. with the receipt of internal remittances. However, with the pooled sample of male headed and female headed households together, the results suggest that female household head spend more budget share on education while it also proves that investment on housing increased with the receipt of international remittances.

The presence of remitter in the household expenditure model indicates that remitters prefer their money spend more on education and less on food. In particular, when the remitter is the spouse of the household head, the expenditure share allocated to education is greater. 
This implies that female remitters want to spend their money less on food and more on education.

Finally, the results suggest that food, housing and consumer goods and durables are necessities and education health and other goods are luxuries in male headed households while food and housing are necessities and education, health, consumer goods and durables and other goods are luxuries in female headed households. However, when the remitter is included in the analysis, food housing and consumer goods are necessities while education, health and other goods are luxuries.

Overall, the findings of the study are important from policy perspective because they support a growing view in the literature that migration and remittances help in developing the estate household economy by reducing increasing the level of household investment in education, health and housing thereby contributing positively to economic development. It is also really important that gender perspective should be included in order to understand the development impacts.

\section{References}

Acosta, P. (2007). School Attendance, Child Labor, and Remittances from International Migration: the Case of El Salvador, document prepared for Congreso Latinoamericano y Caribeño de Ciencias Sociales, FLACSO, 29-31 October, Quito

Ariyarathne, T., Lokuge, G., Najab, N. and Fernando, P. (2012). The vulnerability of women in the economy, Economic Review, Issue on Female Participation in the Economy, Vol 38. Retrieved from http://www.cepa.1k/uploads/4bae1bc28cb6cbe73a08a2bf084b8f a3-120830-ER-The-vulnerability-of-women-in-the-economy--CEPA.pdf

Arunatilake, N., Jayawardena, P. and Weerakoon, D., (2011). Sri Lanka: Migration, Remittances and Development in Migration Remittances and Development in South Asia, in Kelegama, S,(Ed) Sage publishers, New Delhi, pp. 112-140

Chami, R., Fullenkamp, C. and Jahjah, S. (2003). Are Immigrant Remittance Flows a Source of Capital for Development?, International Monetary Fund Working Paper 03/189, Washington D.C. 
De Silva, S. (2013). Long-Term Benefits from Temporary Migration: Does the Gender of the Migrant Matter?, Levy Economics Institute of Bard College, Working Paper No. 756

De la Cruz, B. E. (1995). The Socioeconomic Dimensions of Remittances: A Case Study of Five Mexican Families, Berkeley McNair Journal, vol. 3, pp. 1-10.

Göbel, K. (2013). "Remittances, expenditure patterns, and gender: Parametric and semi parametric evidence from Ecuador", IZA Journal of Migration, vol. (2), pp. 2-9.

Guzmán, J.C., Morrison, A.R. and Sjöblom, M. (2008). The Impact of Remittances and Gender on Household Expenditure Patterns: Evidence from Ghana, In: Morrison, A.R., Schiff, M., Sjöblom, M., (eds), The international migration of women, World Bank and Palgrave Macmillan, pp. 125-152.

Haddad, L., Hoddinott, J. and Alderman, H. (1997). Intra-household Resource Allocation in Developing Countries: Models, Methods, and Policy, Baltimore, MD: Johns Hopkins University Press.

Lasagabaster, E., Maimbo, S.M. and Hulugalle, S. (2005). Sri Lanka's Migrant Labor Remittances: Enhancing the Quality and Outreach of The Rural Remittance Infrastructure, World Bank Policy Research Working Paper 3789, World Bank, Washington D.C

Pfeiffer, L. and Taylor, J.E. (2008). Gender and the Impacts of International Migration: Evidence from Rural Mexico". In Morrison, A. R., Schiff, M., and Sjoblom, M., (eds), The International Migration of Women, World Bank and Palgrave Macmillan, pp 99-124.

Quisumbing, A. and Maluccio, J. (2000). Intra-household Allocation and Gender Relations: New Empirical Evidence from Four Developing Countries, FCND Discussion Paper 84, Washington, DC: International Food Policy Research Institute.

Sharma, M. P. (2013). International Contract-Based Migration, Remittances, and Household Well-Being in the Western Province of Sri Lanka, International Migration, Vol 5, pp, 216248. doi: 10.1111/j.1468-2435.2011.00683.x 
Taylor, J. E., Arango, J., Hugo, G., Kouaouci, A., Massey, D.S., and Pellegrino, A., (1996). International migration and community development. Population Index, vol. 62, No. 3, pp. 397-418.

Vithanage, D.S. (2015). Understanding the Nature and Scope of Patriarchy in Sri Lanka: How Does it Operate in the Institution of Marriage? Culminating Projects in Social Responsibility. Paper 3. http://repository.stcloudstate.edu/socresp_etds/3

World Bank (2007). Sri Lanka Poverty Assessment: Engendering Growth with Equity: Opportunities and Challenges, World Bank, Washington D.C 